\title{
FGF21 attenuates hypoxia-induced dysfunction and apoptosis in HPAECs through alleviating endoplasmic reticulum stress
}

\author{
ALI CHEN $^{1}$, JINGJING LIU ${ }^{1}$, JIANFENG ZHU ${ }^{1}$, XUETAO WANG ${ }^{1}$, \\ ZHAONA XU ${ }^{1}$, ZHIMIN CUI $^{1}$, DAN YAO $^{1}$, ZHIFENG HUANG $^{2}$, MIN XU $^{1}$, MAYUN CHEN $^{1}$, \\ PEILIANG WU ${ }^{1}$, MANXIANG LI ${ }^{3}$, LIANGXING WANG ${ }^{1}$ and XIAOYING HUANG ${ }^{1}$ \\ ${ }^{1}$ Division of Pulmonary Medicine, The First Affiliated Hospital of Wenzhou Medical University, \\ Key Laboratory of Heart and Lung; ${ }^{2}$ Key Laboratory of Biotechnology and Pharmaceutical Engineering of \\ Zhejiang Province, Wenzhou Medical University, Wenzhou, Zhejiang 325000; ${ }^{3}$ Department of Respiratory Medicine, \\ The First Affiliated Hospital of Xi'an Jiaotong University, Xi'an, Shanxi 710061, P.R. China
}

Received December 3, 2017; Accepted May 18, 2018

DOI: $10.3892 /$ ijmm.2018.3705

\begin{abstract}
Vascular endothelial apoptosis and dysfunction have a crucial role in triggering pathological vascular remodeling of hypoxia-induced pulmonary arterial hypertension (PAH). Fibroblast growth factor (FGF)21, an endocrine regulator, has recently been reported to protect cardiac endothelial cells from damage and suppress inflammatory responses. In addition, FGF21 is reported to be involved in endoplasmic reticulum stress (ERS). Previous studies have suggested that
\end{abstract}

Correspondence to: Professor Xiaoying Huang or Professor Liangxing Wang, Division of Pulmonary Medicine, The First Affiliated Hospital of Wenzhou Medical University, Key Laboratory of Heart and Lung, 1 Nanbaixiang Street, Ouhai, Wenzhou, Zhejiang 325000, P.R. China

E-mail: zjwzhxy@126.com

E-mail: wzyxywlx@163.com

Abbreviations: PAH, pulmonary arterial hypertension; ERS, endoplasmic reticulum stress; FGF21, fibroblast growth factor 21; HPAECs, human pulmonary arterial endothelial cells; CCK-8, cell counting kit-8; TUNEL, terminal deoxyribonucleotide transferase-mediated dUTP nick end-labelling assay; BiP, binding immunoglobulin protein; CHOP, transcription factor $\mathrm{C} / \mathrm{EBP}$ homologous protein; PERK, protein kinase R-like endoplasmic reticulum kinase; Bcl-2, B cell lymphoma-2; NO, nitric oxide; ET-1, endothelin-1; COPD, chronic obstructive pulmonary disease; UPR, unfolded protein response; PASMCs, pulmonary artery smooth muscle cells; ECM, endothelial cell media; FBS, fetal bovine serum; ECGS, endothelial cell growth supplement; PBS, phosphate-buffered saline; eIF2 $\alpha$, eukaryotic translation initiation factor $2 \alpha$; IRE1, inositol-requiring enzyme 1; XBP1, X-box binding protein 1; ATF6, activating transcription factor 6; CerS6, ceramide synthase 6; 4-PBA, 4-phenylbutyric acid

Key words: pulmonary arterial hypertension, endoplasmic reticulum stress, fibroblast growth factor 21, human pulmonary arterial endothelial cells
ERS participates in the development of PAH, and attenuation of ERS could be an effective therapeutic strategy for the protection of pulmonary arteries. However, whether FGF21 has a protective function via suppression of ERS in pulmonary arterial endothelial cells in hypoxia remains unclear. The present study aimed to explore whether FGF21 could reduce the hypoxia-induced apoptosis of human pulmonary arterial endothelial cells (HPAECs) and prevent endothelial dysfunction via the inhibition of ERS. HPAECs were divided into six groups: Normoxia, hypoxia, hypoxia plus FGF21, hypoxia plus salubrinal (an ERS inhibitor), hypoxia plus tunicamycin (an ERS agonist), and hypoxia plus tunicamycin plus FGF21. The endoplasmic reticulum ultrastructure in HPAECs was assessed by transmission electron microscopy, and proliferation and apoptosis were examined by cell counting kit- 8 and terminal deoxyribonucleotide transferase-mediated dUTP nick end-labelling assays, respectively. The expression levels of ERS-related proteins, including binding immunoglobulin protein $(\mathrm{BiP})$, protein kinase R-like endoplasmic reticulum kinase (PERK), phosphorylated (p-) PERK, transcription factor C/EBP homologous protein (CHOP), B-cell lymphoma-2 (Bcl-2) and caspase-4 were detected by western blotting. Transwell migration chamber assays were performed, and the concentration of nitric oxide (NO)/endothelin-1 (ET-1) in the culture medium was determined to examine endothelial function. The results revealed that hypoxia increased the \% of apoptotic cells and diminished the viability of HPAECs, accompanied by an upregulation of ERS-dependent apoptosis by increasing the expression of the proapoptotic caspase- 4 and decreasing the antiapoptotic Bcl-2. Additionally, hypoxia upregulated the expression of representative proteins in the PERK branch of ERS, including BiP, p-PERK and CHOP, while it downregulated the expression of PERK. Furthermore, the secretion of NO/ET-1 and the migration rate of HPAECs were downregulated under conditions of hypoxia. FGF21 significantly attenuated the hypoxia-induced apoptosis and dysfunction of HPAECs through alleviating the aforementioned changes in ERS-dependent signaling pathways. In conclusion, ERS may be a crucial mechanism in the hypoxia-induced 
apoptosis and endothelial dysfunction of HPAECs. FGF21 may attenuate the hypoxia-induced apoptosis and dysfunction of HPAECs through alleviating ERS, via the PERK/CHOP signaling pathway and inhibition of caspase-4 expression.

\section{Introduction}

Pulmonary arterial hypertension (PAH) is a vascular remodeling disease of the lungs that results in right ventricular failure and death within a few years of diagnosis (1). Chronic hypoxia-induced $\mathrm{PAH}$, a common type of $\mathrm{PAH}$, is predominantly secondary to disorders of the respiratory system, including chronic obstructive pulmonary disease (COPD) and obstructive sleep apnea (2). Although the precise pathogenesis of hypoxia-induced PAH remains unclear, it is thought that vascular endothelial damage and dysfunction serve a crucial role in triggering pathological vascular remodeling (3). Pulmonary endothelial cell dysfunction in hypoxia-induced PAH has been demonstrated to be associated with decreased production of nitric oxide (NO) and increased production of endothelin-1 (ET-1), which participate in the subsequent abnormal proliferation of pulmonary endothelial cells and pulmonary smooth muscle cells $(4,5)$. In addition, experimental studies have suggested that endothelial cell apoptosis in the pulmonary microvasculature causes arteriolar occlusion and increases pulmonary vascular resistance, suggesting that vascular endothelial cell apoptosis is closely associated with the pathogenesis of PAH $(6,7)$. The mechanisms responsible for endothelial cell apoptosis in the early stages of hypoxia-induced PAH are yet to be fully elucidated.

In recent studies, endoplasmic reticulum stress (ERS) has been demonstrated to have an important role in the development of PAH. Hypoxia, toxicity, infection and perturbation of $\mathrm{Ca}^{2+}$ homeostasis lead to the accumulation of unfolded or misfolded proteins, which results in ERS, activating the adaptive cellular response termed the unfolded protein response (UPR) $(8,9)$. Under mildly stressful conditions, these pathways activate several transcription factors involved in cell survival. However, under conditions of severe acute or chronic stress, the ER UPR shifts from survival to cell death signaling pathways (10). In previous studies, it was identified that ERS participates in the development of PAH in vitro and in vivo. Sutendra and Michelakis (1) reported that, in response to hypoxia-induced stress, the Nogo B protein from mice pulmonary artery smooth muscle cells (PASMCs), which regulates ER structure and has been implicated in vascular remodeling, serves a role in the development of PAH. Koyama et al (11) demonstrated that activation of all branches of the UPR and accompanying inflammation in human pulmonary smooth muscle cells have a major role in the pathogenesis of $\mathrm{PAH}$, and that the chemical chaperones that inhibit ERS may be potential therapeutic agents for PAH. Although studies have indicated that ERS participates in the process of PASMC proliferation in hypoxia-induced PAH, the connection between endothelial dysfunction and ERS in the development of hypoxia-induced PAH remains unclear.

Fan et al (12) demonstrated that ERS-associated proteins and the ERS-dependent apoptotic protein caspase-12 were upregulated and the number of pulmonary apoptotic cells was markedly increased in hypoxia-induced PAH in rats, indicating that ERS-induced apoptosis may be one of the mechanismsunderlying hypoxic pulmonary hypertension and pulmonary vascular wall remodeling. The present studyaimed to investigate whether ERS participates in hypoxia-induced apoptosis and damage in human pulmonary arterial endothelial cells (HPAECs) through in vitro experiments, and to provide additional evidence on the role of ERS in hypoxia-induced PAH.

Fibroblast growth factor (FGF)21, a novel member of the FGF superfamily, is a crucial endogenous regulator of lipid metabolism and systemic glucose. Circulating endogenous FGF21 is elevated in obesity, type 2 diabetes and coronary artery disease. Therefore, FGF21 is considered a stress hormone, mediating the adaptive metabolic response to various stress conditions (13). In addition, FGF21 is reported to be involved in various pathological conditions, including fatty liver disease, ERS, and chronic inflammation (14). Recent studies have indicated that both triglycerides and tunicamycin-induced ERS stimulate FGF21 expression in hepatocytes and increase serum levels of FGF21, indicating that FGF21 has a crucial role in ERS (15,16). Guo et al (17) demonstrated that administration of FGF21 restores insulin signaling via inhibiting ERS in the adipose tissue of high-fat diet-induced obese mice. In addition, FGF21 has been reported to protect cardiac endothelial cells from damage and to suppress inflammatory responses (18). FGF21 may be a signal of injured target tissue and may have physiological roles in improving endothelial function at an early stage of atherosclerosis and in halting the development of coronary heart disease (18). It is well known that there are many similarities between the cardiovascular system and the pulmonary vasculature. However, research regarding the associations between FGF21 and PAH is limited. Whether FGF21 could protect endothelial cells from damage, as is the case in the cardiovascular system, remains poorly delineated. Considering the aforementioned relationship between FGF21 and ERS, the present study hypothesized that FGF21 could decrease hypoxia-induced apoptosis and repair damage to HPAECs to improve endothelial function though alleviating ERS.

\section{Materials and methods}

Reagents. Salubrinal (an ERS inhibitor; cat. no. SML0951) and tunicamycin (an ERS agonist; cat. no. T7765) were obtained from Sigma-Aldrich; Merck KGaA (Darmstadt, Germany). Rabbit antibodies against binding immunoglobulin protein (BiP), protein kinase R-like endoplasmic reticulum kinase (PERK), B-cell lymphoma-2 (Bcl-2), caspase-4 and GAPDH were purchased from Cell Signaling Technology, Inc. (Danvers, MA, USA). Rabbit antibodies against phosphorylated (p-) PERK were purchased from Biorbyt (Cambridge, UK). Mouse antibodies against cluster of differentiation 31 (CD31) and transcription factor $\mathrm{C} / \mathrm{EBP}$ homologous protein $(\mathrm{CHOP})$ were purchased from Abcam (Cambridge, UK) and Cell Signaling Technology, Inc., respectively. An anti-mouse immunoglobulin $\mathrm{G}(\mathrm{IgG})$ horseradish peroxidase (HRP)-linked antibody and an anti-rabbit IgG HRP-linked antibody were purchased from Cell Signaling Technology, Inc. FGF21 was obtained from the Wenzhou Medical College Pharmacy School (Wenzhou, China). Endothelial 
cell medium (ECM; 1001), fetal bovine serum (FBS) and an endothelial cell growth supplement (ECGS) were purchased from ScienCell Research Laboratories, Inc. (San Diego, CA, USA). Phosphate-buffered saline (PBS) was purchased from Hyclone; GE Healthcare Life Sciences (Logan, UT, USA). The cell counting kit-8 (CCK-8) was purchased from Dojindo Molecular Technologies (Kumamoto, Japan). The ELISA kit was purchased from BoyunBiotechnology Company (Shanghai, China). The terminal deoxyribonucleotide transferase-mediated dUTP nick end-labelling (TUNEL) kit was purchased from Roche Diagnostics (Basel, Switzerland).

Cell lines and cell culture. HPAECs (cat. no. 3100) were purchased from ScienCell Research Laboratories, Inc., and used as previously described (19). The HPAECs were cultured in ECM, supplemented with 5\% FBS, 1\% ECGS, $100 \mathrm{U} / \mathrm{ml}$ penicillin and $100 \mu \mathrm{g} / \mathrm{ml}$ streptomycin. The medium was changed every 2 days. When the cells reached $80-90 \%$ confluence, they were washed with PBS and treated with $0.05 \%$ trypsin-EDTA for passaging. The cells were identified through microscopy and by positive staining for CD31 (Fig. 1A). For experimental use, HPAECs from passages 3-5 were sub cultured and randomly divided into 6 groups: Normoxia group $(\mathrm{N})$; hypoxia group $(\mathrm{H})$; hypoxia+FGF21 group $(\mathrm{H}+\mathrm{F})$; hypoxia+salubrinal (ERS inhibitor; $20 \mu \mathrm{M}$ ) group (H+S), with the concentrations used determined from a previous study (20); hypoxia+tunicamycin (ERS agonist; $2.5 \mathrm{ng} / \mathrm{ml}$ ) group (H+T) with the concentrations used determined from a previous study (21); and hypoxia+tunicamycin+FGF21 group ( $\mathrm{H}+\mathrm{T}+\mathrm{F})$. The $\mathrm{H}+\mathrm{F}$ group was subdivided into 5 groups with different concentrations of FGF21, as follows: $\mathrm{H}+\mathrm{F}$ (100 ng/ml), H+F (200 ng/ml), H+F (400 ng/ml), H+F (800 ng/ml) and H+F $(1,600 \mathrm{ng} / \mathrm{ml})$, to obtain the optimum concentration of FGF21. Hypoxia-treated HPAECs were treated as aforementioned for $24 \mathrm{~h}$. All hypoxia groups were kept for $24 \mathrm{~h}$ in the hypoxia incubator at $37^{\circ} \mathrm{C}$ with $5 \% \mathrm{CO}_{2}, 5 \% \mathrm{O}_{2}$ and $90 \% \mathrm{~N}_{2}$, with these conditions based on the results of previous studies $(22,23)$, whereas the normoxia group was maintained in a normal incubator at $37^{\circ} \mathrm{C}$ with $21 \% \mathrm{O}_{2}, 5 \% \mathrm{CO}_{2}$ and $74 \% \mathrm{~N}_{2}$.

Cell viability assay. Cell viability was quantified through CCK-8 assays. HPAECs were seeded at a density of $1 \times 10^{4}$ cells/well in flat-bottomed 96 -well plates. Following pre-incubation in complete medium at $37^{\circ} \mathrm{C}$ and in $21 \% \mathrm{O}_{2}$ and $5 \% \mathrm{CO}_{2}$ for $24 \mathrm{~h}$, HPAECs were pretreated with FGF21, salubrinal and tunicamyc in prior to exposure to hypoxia. Cell viability was observed under a microscope before the CCK-8 assay. Cell viability was observed under a light microscope (magnification, x100) prior to the CCK-8 assays. After $24 \mathrm{~h}$ of hypoxia, the CCK-8 reagent (10 $\mu \mathrm{l} /$ well) was added to each well. Following incubation at $37^{\circ} \mathrm{C}$ for $2 \mathrm{~h}$, the absorbance of each well was determined using a micro plate reader at $450 \mathrm{~nm}$. Cell viability was determined based on the absorbance of each well.

Detection of apoptosis. Cell apoptosis was evaluated using the TUNEL assay (In Situ Cell Death Detection Kit, POD), according to the manufacturer's protocol. HPAECs were exposed to hypoxia and treated with or without the reagents indicated above. Following the treatment, the cells adhered to cover slips and were fixed with $4 \%$ paraformaldehyde in PBS ( $\mathrm{pH} \mathrm{7.4)} \mathrm{for} 1 \mathrm{~h}$ at $25^{\circ} \mathrm{C}$. The cells were then subjected to TUNEL assays, according to the manufacturer's protocol. DAB was employed as the chromogen and hematoxylin as the counterstain. Finally, the cover slips were observed via light microscopy, and the \% of TUNEL-positive cells was assessed in six randomly selected fields from each cover slip.

Ultrastructural examination of the endoplasmic reticulum of HPAECs. HPAECs were cultured in $25 \mathrm{~cm}^{2}$ flasks. At the end of the hypoxia exposure period, the HPAECs were washed with PBS and treated with $0.05 \%$ trypsin-EDTA to collect cells. Cell aggregates were fixed with $2.5 \%$ glutaraldehyde and $1 \%$ osmic acid for 1 hat $37^{\circ} \mathrm{C}$, prior to being dehydrated with acetone and embedded in epoxy resin 812 . The fixed cell aggregates were subsequentlycut into ultrathin sections (the thickness of the sections was $\sim 50 \mathrm{~nm}$ ) with an ultramicrotome and examined with a Hitachi H-7500 transmission electron microscope (Hitachi, Ltd., Tokyo, Japan) following staining with uranyl acetate and lead citrate for $3-6 \mathrm{~h}$ at $45^{\circ} \mathrm{C}$ and for $48 \mathrm{~h}$ at $65^{\circ} \mathrm{C}$, respectively. Three fields were obtained randomly.

Western blot analysis. Following treatment, HPAECs were lysed with ice-cold RIPA lysis buffer containing PMSF for $30 \mathrm{~min}$. Then, the lysates were centrifuged at $16,000 \mathrm{x} \mathrm{g}$ for $30 \mathrm{~min}$ at $4^{\circ} \mathrm{C}$, and the supernatant was collected. The protein concentrations were determined using a Pierce bicinchoninic acid protein assay kit. Equal amounts of protein $(20 \mu \mathrm{g})$ were then separated by $12 \%$ SDS-PAGE, transferred onto polyvinylidene fluoride membranes, blocked with $5 \%$ milk for $1 \mathrm{~h}$ at room temperature, and incubated overnight with specific primary rabbit antibodies against BiP (dilution, 1:1,000; 3183), PERK (dilution, 1:1,000; 3192), p-PERK (dilution, 1:100; orb6693), Bcl-2 (dilution, 1:1,000; 2870), caspase-4 (dilution, 1:1,000; ab22687) and GAPDH (dilution, 1:1,000; 5174S) and a mouse antibody against $\mathrm{CHOP}$ (dilution, $1: 1,000 ; 2895)$ at $4^{\circ} \mathrm{C}$. The membranes were subsequently washed with $\mathrm{TBS} / 0.1 \%$ Tween-20 (TBST) buffer and membranes that had been incubated with anti-BiP, anti-PERK, anti-p-PERK, anti-Bcl-2, anti-caspase-4 and anti-GAPDH antibodies were incubated with anti-rabbit IgG HRP-linked antibody (dilution, 1:10,000; 7074), while membranes that had been incubated with the anti-CHOP antibody were incubated with an anti-mouse IgG HRP-linked antibody (dilution, 1:10,000; 7076) for $1 \mathrm{~h}$ at room temperature. Super Signal West Fem to Maximum Sensitivity substrate (cat. no. 3409; Shanghai Boyun BioTech Co., Ltd., Shanghai, China) was used as the visualization reagent. GAPDH was used as an internal control. The optical density of the immune blots was quantified with Quantityone-4.6.2 software (Bio-Rad Laboratories, Inc., Hercules, CA, USA).

Transwell migration chamber assay. The 24-well Transwell system (5 $\mu \mathrm{m}$; Corning Incorporated, Corning, NY, USA) was used to perform cell migration assays. A total of $600 \mu \mathrm{l}$ ECM, containing 5\% FBS was added to the lower chamber with the experimental treatments. Then, HPAECs were suspended in ECM without serum, and $200 \mu \mathrm{l}$ cell suspension (at a density of $1.5 \times 10^{5} / \mathrm{ml}$ ) was added to the upper chambers of the Transwell plates. Following incubation at $37^{\circ} \mathrm{C}$ for $24 \mathrm{~h}$, the non-migrated cells were removed using a cotton swab. The 
A

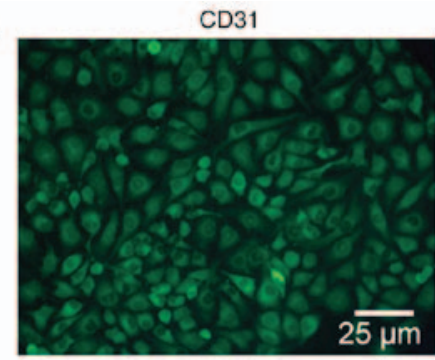

DAPI

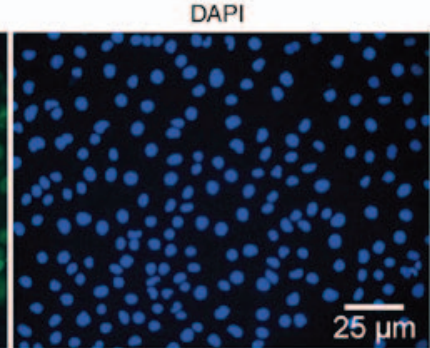

Merge

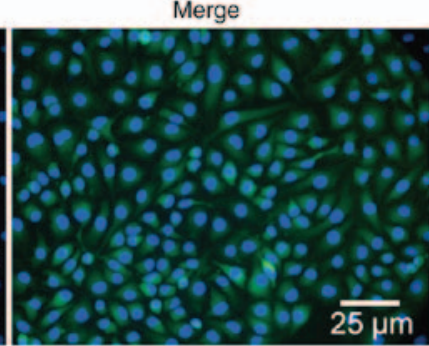

B
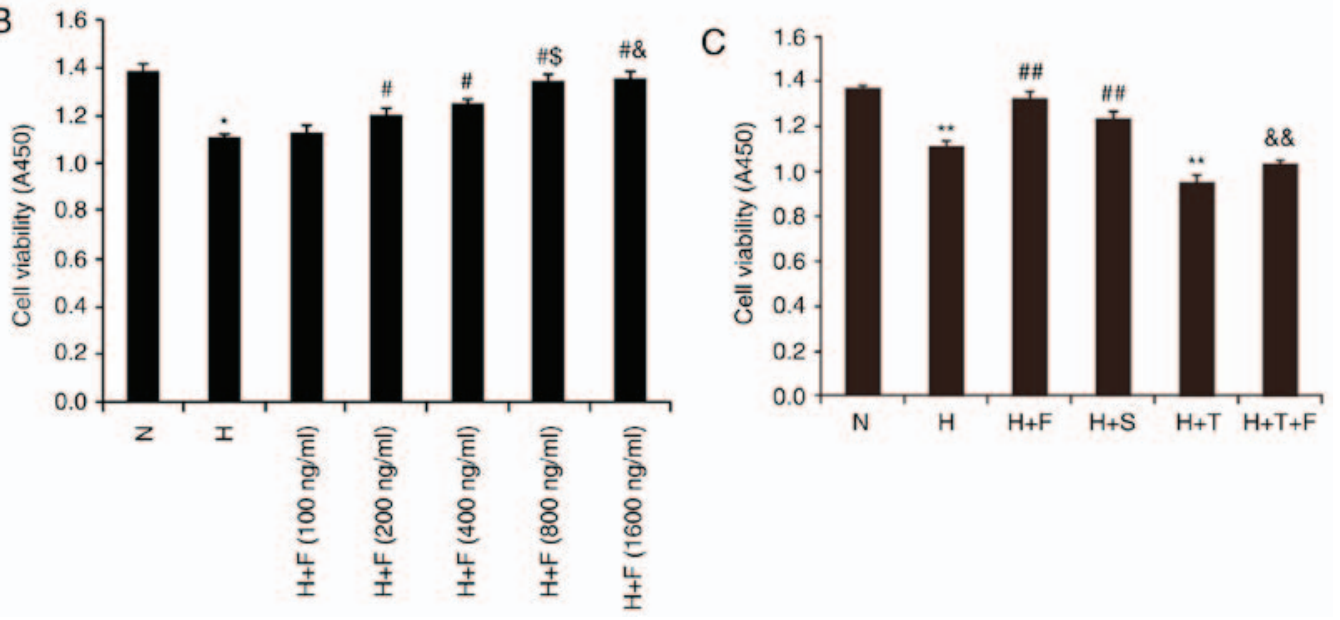

Figure 1. Characterizationof HPAECs and cell viability in different experimental groups. (A) HPAECs were identified by microscopy, based on positive staining for CD31 (magnification, x100; scale bar, $25 \mu \mathrm{m}$ ). CD31 staining appears green in the images, while nuclei are counterstained with DAPI and appear blue. (B) HPAECs were exposed to hypoxia and treated with different concentrations of FGF21 (100, 200, 400, 800 and 1,600 ng/ml). Absorbance of cell counting kit-8 at $450 \mathrm{~nm}$ in HPAECs was used to determine the relative cell number and viability. (C) HPAECs were exposed to hypoxia and treated with FGF21 $(800 \mathrm{ng} / \mathrm{ml})$, ERS inhibitor salubrinal $(20 \mu \mathrm{M})$, ERS agonist tunicamycin $(2.5 \mathrm{ng} / \mathrm{ml})$ or tunicamycin plus FGF21. Cell viability was analyzed via CCK- 8 assays. The absorbance of CCK- 8 at $450 \mathrm{~nm}$ was used to determine the relative cell numbers and viability. Data are expressed as the mean \pm standard deviation $(\mathrm{n}=6)$. ${ }^{*} \mathrm{P}<0.05$ vs. the $\mathrm{N}$ group; ${ }^{* *} \mathrm{P}<0.01$ vs. the $\mathrm{N}$ group; ${ }^{\#} \mathrm{P}<0.05$ vs. the $\mathrm{H}$ group; ${ }^{\# \prime} \mathrm{P}<0.01$ vs. the $\mathrm{H}$ group; ${ }^{\$} \mathrm{P}<0.05$ vs. the $\mathrm{H}+\mathrm{F}(400 \mathrm{ng} / \mathrm{ml})$; ${ }^{\&} \mathrm{P}>0.05$ vs. the H+T group $(800 \mathrm{ng} / \mathrm{ml}) ;{ }^{\&}{ }^{\mathrm{P}}<0.01$ vs. the H+T group. HPAECs, human pulmonary arterial endothelial cells; FGF21, fibroblast growth factor 21; ERS, endoplasmic reticulum stress; CCK-8, cell counting kit-8; N, normoxia; H, hypoxia; F, FGF21; S, salubrinal; T, tunicamycin.

migrated cells were then fixed with $4 \%$ paraformaldehyde for $10 \mathrm{~min}$, followed by staining with crystal violet for $30 \mathrm{~min}$. Finally, the number of migrated cells was counted under a microscope (Nikon Corporation, Tokyo, Japan), six fields were obtained randomly.

ELISA of NO and ET-1. The accumulated NO and ET-1 levels in the culture medium were determined using ELISA kits (NO, cat. no. $30417 \mathrm{H}$; ET-1, cat. no. $30538 \mathrm{H}$ ), according to the manufacturer's protocol.

Statistical analysis. All of the experiments were repeated at least three times. The results are expressed as the mean \pm standard deviation. Statistical significance was determined by one-way analysis of variance, followed by the least significant difference (LSD) test (equal variances assumed) or Dunnett's T3 test (equal variances not assumed). $\mathrm{P}<0.05$ was considered to indicate a statistically significant difference. All calculations were performed using SPSS version 20.0 (IBM Corporation, Armonk, NY, USA).

\section{Results}

Hypoxia and the ERS agonist tunicamycin reduce the viability of HPAECs, and this effect is improved by FGF21 and the ERS inhibitor salubrinal. The absorbance measured at $450 \mathrm{~nm}$ in
HPAECs subjected to the CCK-8 assay was used to determine relative cell numbers and viability. As indicated in Fig. 1B, the absorbance was reduced in the $\mathrm{H}$ group compared with the $\mathrm{N}$ group $(\mathrm{P}<0.05)$. Under cotreatment with FGF21, the absorbance was significantly enhanced in the $\mathrm{H}+\mathrm{F}(200 \mathrm{ng} / \mathrm{ml})$, $\mathrm{H}+\mathrm{F}(400 \mathrm{ng} / \mathrm{ml}), \mathrm{H}+\mathrm{F}(800 \mathrm{ng} / \mathrm{ml})$ and $\mathrm{H}+\mathrm{F}(1,600 \mathrm{ng} / \mathrm{ml})$ compared with the $\mathrm{H}$ group $(\mathrm{P}<0.05$; Fig. 1B). The absorbance was significantly increased in the $\mathrm{H}+\mathrm{F}(800 \mathrm{ng} / \mathrm{ml})$ group compared with the $\mathrm{H}+\mathrm{F}(400 \mathrm{ng} / \mathrm{ml})$ group $(\mathrm{P}<0.05$; Fig. $1 \mathrm{~B})$. Meanwhile, compared with the $\mathrm{H}+\mathrm{F}(800 \mathrm{ng} / \mathrm{ml})$ group, there was no significance in the increase of absorbance in the $\mathrm{H}+\mathrm{F}$ $(1,600 \mathrm{ng} / \mathrm{ml})(\mathrm{P}>0.05$; Fig. 1B). We chose $800 \mathrm{ng} / \mathrm{ml}$ as the optimum concentration of FGF21 in subsequent experiments.

As indicated in Fig. 1C, the absorbance was reduced in the $\mathrm{H}$ group and the $\mathrm{H}+\mathrm{T}$ group compared with that of the $\mathrm{N}$ group $(\mathrm{P}<0.01)$. Under co-treatment with FGF21 or salubrinal, the absorbance was significantly enhanced in the $\mathrm{H}+\mathrm{F}$ and $\mathrm{H}+\mathrm{S}$ groups compared with that of the $\mathrm{H}$ group $(\mathrm{P}<0.01)$. The absorbance was increased in the $\mathrm{H}+\mathrm{T}+\mathrm{F}$ group compared with that of the $\mathrm{H}+\mathrm{T}$ group $(\mathrm{P}<0.01)$. The results indicated that FGF21, as well as the ERS inhibitor salubrinal, improved the viability of HPAECs under conditions of hypoxia.

Hypoxia and the ERS agonist tunicamycin increase apoptosis, and this effect is reversed by FGF21 and the ERS inhibitor salubrinal. The effects of FGF21 on the apoptosis of HPAECs 

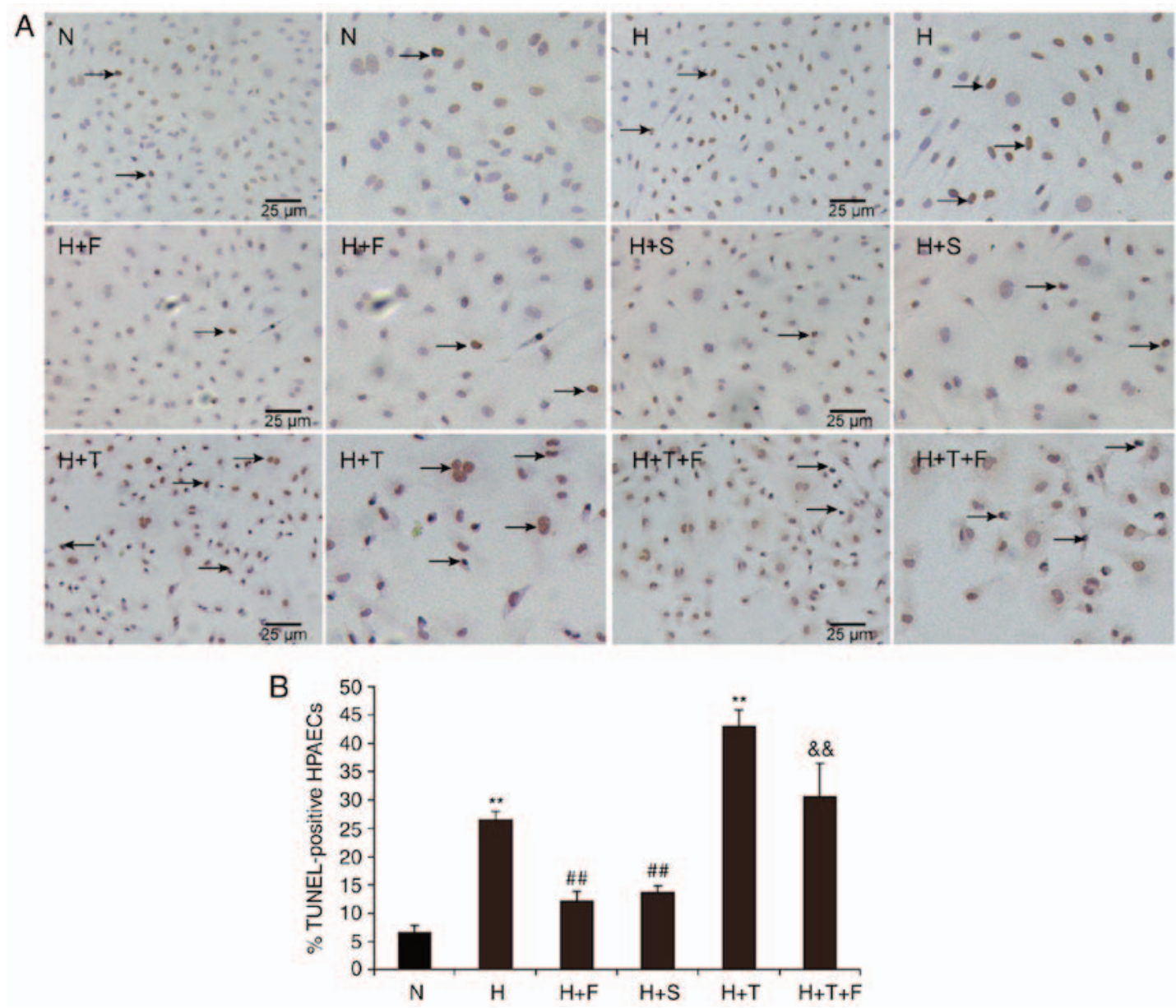

Figure 2. (A and B) Hypoxia increases the apoptosis of HPAECs, and this is reversed by FGF21. The HPAECs from each experimental group were stained with the TUNEL reagent and analyzed by microscopy (magnification, x100; scale bar, $25 \mu \mathrm{m}$ ). The arrows denote TUNEL-positive apoptotic HPAECs (brown staining). Data are expressed as the mean \pm standard deviation $(\mathrm{n}=6){ }^{* * *} \mathrm{P}<0.01$ vs. the $\mathrm{N}$ group; ${ }^{\# \#} \mathrm{P}<0.01$ vs. the $\mathrm{H}$ group; ${ }^{\&} \mathrm{P}<0.01$ vs. the $\mathrm{H}+\mathrm{T}$ group. HPAECs, human pulmonary arterial endothelial cells; FGF21, fibroblast growth factor 21; TUNEL, terminal deoxyribonucleotide transferase-mediated dUTP nick end-labelling assay; N, normoxia; H, hypoxia; F, FGF21; S, salubrinal; T, tunicamycin.

were evaluated by TUNEL assays. As illustrated in Fig. 2 , the \% of apoptotic HPAECs (indicated by brown-stained cell nuclei) was significantly increased in the $\mathrm{H}$ group compared with the $\mathrm{N}$ group $(\mathrm{P}<0.01)$. FGF21 or salubrinal treatment decreased the $\%$ of apoptotic cells in the $\mathrm{H}+\mathrm{F}$ and $\mathrm{H}+\mathrm{S}$ groups compared with the $\mathrm{H}$ group $(\mathrm{P}<0.01$; Fig. 2$)$. There was a significant increase in TUNEL-positive cells in the $\mathrm{H}+\mathrm{T}$ group compared with the $\mathrm{N}$ group $(\mathrm{P}<0.01$; Fig. 2), but cotreatment with FGF21 attenuated cell apoptosis in the $\mathrm{H}+\mathrm{T}+\mathrm{F}$ group $(\mathrm{P}<0.01$; Fig. 2$)$. These findings were consistent with the protective function of FGF21 in cardiac endothelial cells (18), suggesting that FGF21 could decrease the rate of apoptosis induced by hypoxia and protect HPAECs from damage or stress.

FGF 21 reverses the hypoxia-induced endoplasmic reticulum dilation of HPAECs. To determine whether FGF21 could protect HPAECs against hypoxia-induced ERS, the cells were examined at the ultrastructural level. Compared with the $\mathrm{N}$ group, the rough endoplasmic reticulum lumens of the H group and the $\mathrm{H}+\mathrm{T}$ group were notably expanded, and ribosomeshad become detached from the endoplasmic reticulum (Fig. 3). In the $\mathrm{H}+\mathrm{F}$ and the $\mathrm{H}+\mathrm{S}$ groups, the expansion of the endoplasmic reticulum lumen was reversed by FGF21 or salubrinal, similar to the normoxia group (Fig. 3). The endoplasmic reticulum lumen of the $\mathrm{H}+\mathrm{T}$ group was considerablyexpanded, while the endoplasmic reticulum lumen of the $\mathrm{H}+\mathrm{T}+\mathrm{F}$ group was not repaired well, and mild expansion of the endoplasmic reticulum lumen continued to be observedin the $\mathrm{H}+\mathrm{T}+\mathrm{F}$ group (Fig. 3). These results indicated that FGF21 is a protective factor that could reverse the hypoxia-induced endoplasmic reticulum dilation of HPAECs.

FGF21 alleviates hypoxia-induced ERS via the PERK/CHOP signaling pathway and via inhibition of caspase-4 expression. In the present study, the roles of the PERK branch and the ERS-dependent apoptosis factor caspase-4 were examined, as regulators of ERS in hypoxia-induced HPAEC damage. To this effect, the protein expression levels of these proteins were measured by western blotting.

The expression of representative proteins in the PERK branch of ERS, including BiP, p-PERK and CHOP, was significantly increased by hypoxia in the $\mathrm{H}$ group compared with the $\mathrm{N}$ group $(\mathrm{P}<0.01$; Fig. $4 \mathrm{~A}, \mathrm{~B}$ and $\mathrm{D})$. This result indicated that the PERK branch of ERS was activated under hypoxic conditions in HPAECs. FGF21 or salubrinal treatment reduced the expression of $\mathrm{BiP}, \mathrm{p}-\mathrm{PERK}$ and $\mathrm{CHOP}$ in the $\mathrm{H}+\mathrm{F}$ and $\mathrm{H}+\mathrm{S}$ groups, respectively, compared the $\mathrm{H}$ group $(\mathrm{P}<0.01$; Fig. 4A, B and D). The expression of BiP, p-PERK and CHOP 


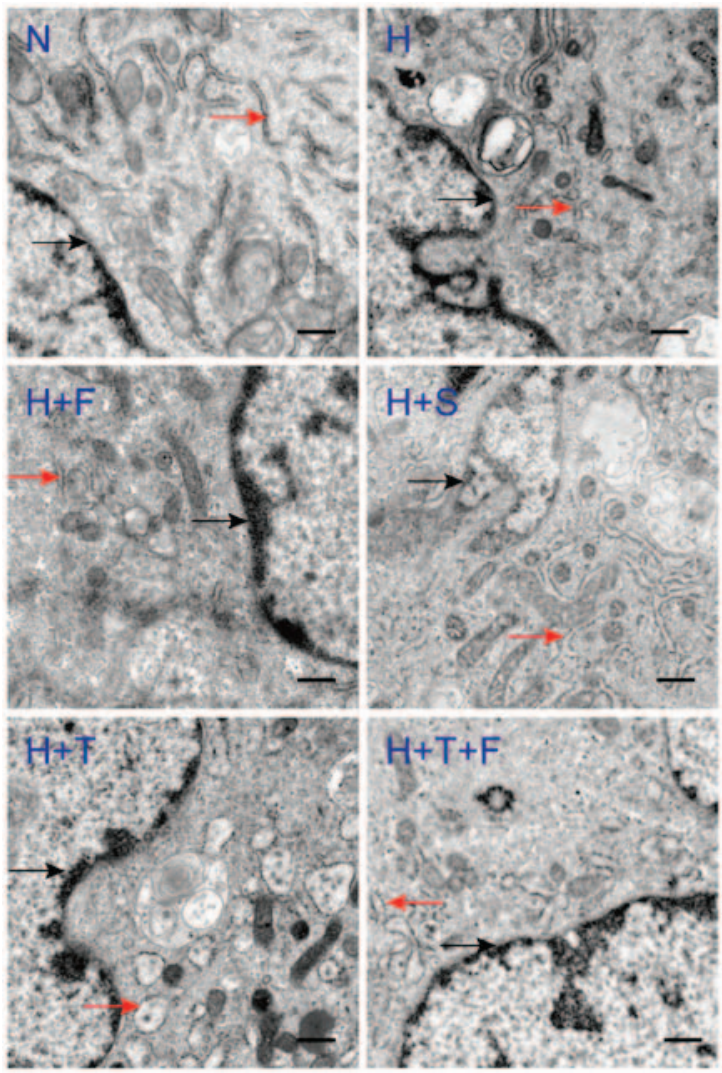

Figure 3. FGF21 reverses the hypoxia-induced endoplasmic reticulum dilation in HPAECs. Ultrathin sections of HPAECs from each experimental group were observed under a Hitachi H-7500 transmission electron microscope. Representative images are shown from three random fields per group. The red arrow denotes the endoplasmic reticulum, and the black arrow denotes the nuclear membrane. Scale bar, $0.5 \mu \mathrm{m}$. FGF21, fibroblas growth factor 21; HPAECs, human pulmonary arterial endothelial cells N, normoxia; H, hypoxia; F, FGF21; S, salubrinal; T, tunicamycin.

was significantly increased in the $\mathrm{H}+\mathrm{T}$ group compared with the $\mathrm{N}$ group $(\mathrm{P}<0.01$; Fig. $4 \mathrm{~A}, \mathrm{~B}$ and $\mathrm{D})$, but cotreatment with FGF21 attenuated their expression in the $\mathrm{H}+\mathrm{T}+\mathrm{F}$ group $(\mathrm{P}<0.01$; Fig. 4A, B and D). By contrast, the expression of PERK exhibited the opposite trend to the expression of p-PERK (Fig. 4B). The ratio of $\mathrm{p}$-PERK/PERK exhibited a consistent trend with the expression of p-PERK (Fig. 4B and C).

The antiapoptotic mediator $\mathrm{Bcl}-2$ is a downstream target of $\mathrm{CHOP}$, which can downregulate the expression of $\mathrm{Bcl}-2$, thereby increasing the rate of apoptosis. In the present study, the expression of $\mathrm{Bcl}-2$ was downregulated in the $\mathrm{H}$ group and the $\mathrm{H}+\mathrm{T}$ group compared with theN group $(\mathrm{P}<0.01$; Fig. $4 \mathrm{E})$. FGF21 or salubrinal treatment increased the expression of $\mathrm{Bcl}-2$ in the $\mathrm{H}+\mathrm{F}$ and $\mathrm{H}+\mathrm{S}$ groups compared with the $\mathrm{H}$ group $(\mathrm{P}<0.01$; Fig. 4E).

The expression of the ERS-induced apoptosis protein caspase- 4 was significantly elevated in the $\mathrm{H}$ group and the $\mathrm{H}+\mathrm{T}$ group compared with the $\mathrm{N}$ group $(\mathrm{P}<0.01$; Fig. $4 \mathrm{~F})$. Under cotreatment with FGF21 or salubrinal, the expression of caspase- 4 was reduced in the $\mathrm{H}+\mathrm{F}$ and $\mathrm{H}+\mathrm{S}$ groups, respectively, compared with the $\mathrm{H}$ group $(\mathrm{P}<0.01$; Fig. $4 \mathrm{~F})$. The expression of caspase- 4 was decreased in the $\mathrm{H}+\mathrm{T}+\mathrm{F}$ group comparedwiththe $\mathrm{H}+\mathrm{T}$ group $(\mathrm{P}<0.01$; Fig. $4 \mathrm{~F})$. In summary, the present findings indicate, for the first time, that ERS is one of the crucial mechanisms in hypoxia-induced HPAEC apoptosis, which was reversed by FGF21 through modulation of the PERK/CHOP signaling pathway and inhibition of caspase-4 expression.

Hypoxia and the ERS agonist tunicamycin inhibit the migratory ability of HPAECs, and this effect is improved by FGF 21 and the ERS inhibitor salubrinal. As indicated in Fig. 5, the migratory ability of HPAECs was decreased in the $\mathrm{H}$ group compared with the $\mathrm{N}$ group $(\mathrm{P}<0.01)$. The migratory ability of HPAECs was significantly increased in the $\mathrm{H}+\mathrm{F}$ and $\mathrm{H}+\mathrm{S}$ groups compared with the $\mathrm{H}$ group $(\mathrm{P}<0.01$; Fig. 5). There was a significant reduction inthe number ofmigrated cells in the $\mathrm{H}+\mathrm{T}$ group compared with the $\mathrm{N}$ group $(\mathrm{P}<0.01$; Fig. 5$)$, but cotreatment with FGF21 increased the number of migrated cells in the $\mathrm{H}+\mathrm{T}+\mathrm{F}$ group $(\mathrm{P}<0.01$; Fig. 5$)$.

Hypoxia and the ERS agonist tunicamycin reduce the secretion of NO and increase the secretion of ET-1, and these effects are reversed by FGF21 and the ERS inhibitor salubrinal. As presented in Fig. 6A, the secretion of NO was decreased in the $\mathrm{H}$ group and the $\mathrm{H}+\mathrm{T}$ group compared with the $\mathrm{N}$ group $(\mathrm{P}<0.01)$. NO secretion was enhanced under FGF21 or salubrinal treatment in the $\mathrm{H}+\mathrm{F}$ and $\mathrm{H}+\mathrm{S}$ groups, respectively, compared with the $\mathrm{H}$ group $(\mathrm{P}<0.05$; Fig. $6 \mathrm{~A})$. $\mathrm{NO}$ secretion was increased in the $\mathrm{H}+\mathrm{T}+\mathrm{F}$ group compared with the $\mathrm{H}+\mathrm{T}$ group $(\mathrm{P}<0.01$; Fig. $6 \mathrm{~A})$. As far as ET-1 secretion is concerned, ET-1 levels were upregulated by hypoxia in the $\mathrm{H}$ group compared with the $\mathrm{N}$ group $(\mathrm{P}<0.01$; Fig. $6 \mathrm{~B})$. FGF21 or salubrinal treatment decreased the secretion of ET-1 in the $\mathrm{H}+\mathrm{F}$ and $\mathrm{H}+\mathrm{S}$ groups, respectively, compared with the $\mathrm{H}$ group $(\mathrm{P}<0.01$; Fig. $6 \mathrm{~B})$. The secretion of ET-1 was significantly increased in the $\mathrm{H}+\mathrm{T}$ group compared with the $\mathrm{N}$ group $(\mathrm{P}<0.01$; Fig. $6 \mathrm{~B})$, but cotreatment with FGF21 reduced the secretion of $\mathrm{ET}-1$ in the $\mathrm{H}+\mathrm{T}+\mathrm{F}$ group $(\mathrm{P}<0.01$; Fig. 6B). The balance of NO and ET-1 production has a key role in the function of endothelial cells. Hence, the presentfindings suggested that FGF21 could improve endothelial function and protect HPAECs from damage by regulating the secretion of NO and ET-1.

\section{Discussion}

Abnormal growth of PASMCs, endothelial cell, fibroblasts, and myofibroblastsis involved in the development of vascular remodeling in hypoxia-induced $\mathrm{PAH}$. The pathology of PAH is also characterized by infiltration of activated inflammatory and immune circulating cells. Among the cells types found within remodeling pulmonary arteries, PASMCs have been the predominant subject of scientific research, but pulmonary artery endothelial cells (PAECs) are also increasingly studied (24). None of the drugs currently available for treating PAH have been demonstrated to effectively reverse the disease or significantly improve long-term survival (1). The present study demonstrated that hypoxia-stimulated ERS contributes towards endothelial apoptosis and dysfunction, which is one of the etiologies for hypoxia-induced PAH.

The data from the current study indicated that the expression of ERS-associated proteins BiP, p-PERK, CHOP and caspase-4 was significantly increased in HPAECs exposed to hypoxia. This was accompanied by an increased rate of 
A

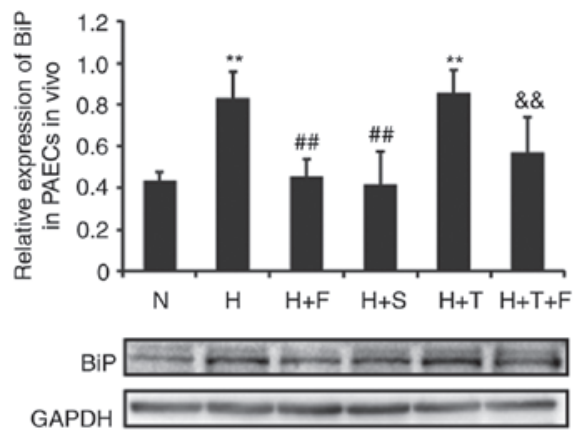

B
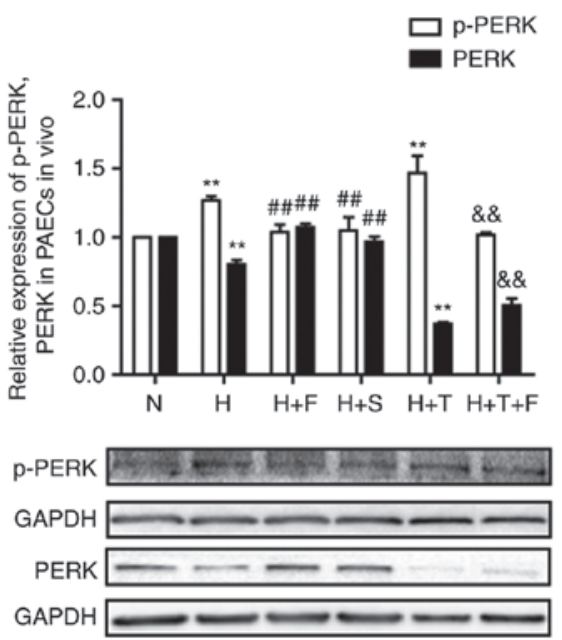

C

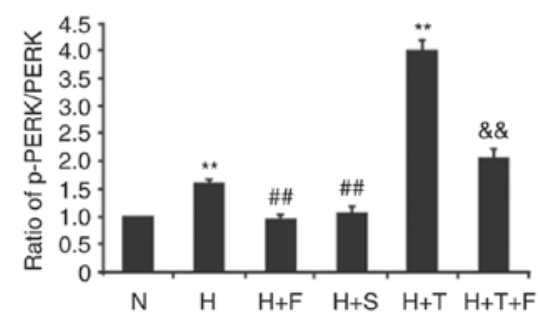

D

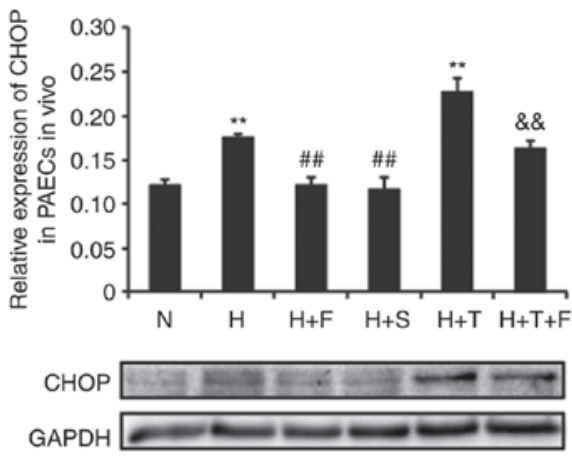

E

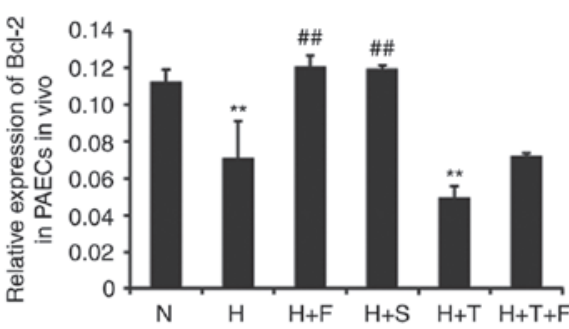

$\mathrm{BCl}-2 \square-\square-\cdots$

GAPDH $=-\cdots$

$\mathrm{F}$

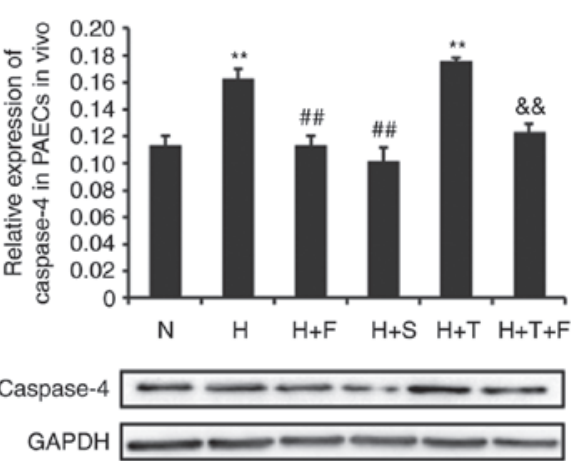

Figure 4. FGF21 alleviates the hypoxia-induced ERS by modulating the expression of ERS-related proteins in HPAECs. HPAECs were treated as indicated and protein expression levels were examined by western blotting. Representative blots and quantification are shown for (A) BiP, (B) p-PERK and PERK, (C) the ratio of p-PERK/PERK, (D) CHOP, (E) Bcl-2. (F) Relative expression of the ERS-dependent apoptotic protein caspase-4 in HPAECs was analysed by western blotting. GAPDH was used as an internal control. All experiments were performed in triplicate, and data are expressed as the mean \pm standard deviation ( $\mathrm{n}=3$ ) ${ }^{* * *} \mathrm{P}<0.01 \mathrm{vs}$. $\mathrm{N}$ group; ${ }^{\# \#} \mathrm{P}<0.01$ vs. the $\mathrm{H}$ group; ${ }^{\&}{ }^{\mathrm{P}} \mathrm{P}<0.01$ vs. the $\mathrm{H}+\mathrm{T}$ group. FGF21, fibroblast growth factor 21; ERS, endoplasmic reticulum stress; HPAECs, human pulmonary arterial endothelial cells; BiP, binding immunoglobulin protein; p-, phosphorylated; PERK, protein kinase R-like endoplasmic reticulum kinase; CHOP, transcription factor C/EBP homologous protein; Bcl-2, B cell lymphoma-2; N, normoxia; H, hypoxia; F, FGF21; S, salubrinal; T, tunicamycin.

apoptosis and damagedmigratoryand secretory abilities, indicating that hypoxic conditions stimulate ERS, which in turn may induce endothelial apoptosis and dysfunction in HPAECs. These results are consistent with those of previous reports $(12,25)$, where expression of the ERS marker proteins glucose-regulated protein (GRP)78, GRP94 andcaspase-12 were demonstrated to be upregulated in hypoxia-induced PAH in rats, additionally, the number of pulmonary apoptotic cells in the hypoxia group was markedly increased compared withthe control group $(12,25)$, suggesting that ERS-induced apoptosis may be one of the mechanisms underlying hypoxic pulmonary hypertension and pulmonary vascular wall remodeling.
Under cellular stress, the ERS activates three branches of the UPR: The double-stranded RNA-activated PERK/eukaryotic translation initiation factor $2 \alpha$ (eIF $2 \alpha$ ) pathway; the inositol-requiring enzyme 1 (IRE1)/X-box binding protein 1 (XBP1) pathway; and the activating transcription factor 6 (ATF6) pathway (26).

PERK is a key ER resident transmembrane molecule whose activation is thought to be the first event in sensing the UPR (10). In resting cells under physiological conditions, as one of the most highly expressed ER chaperones, BiP (GRP78) binds to PERK. Under the effects of harmful stress, PERK disassociates from BiP and is activated by 
A

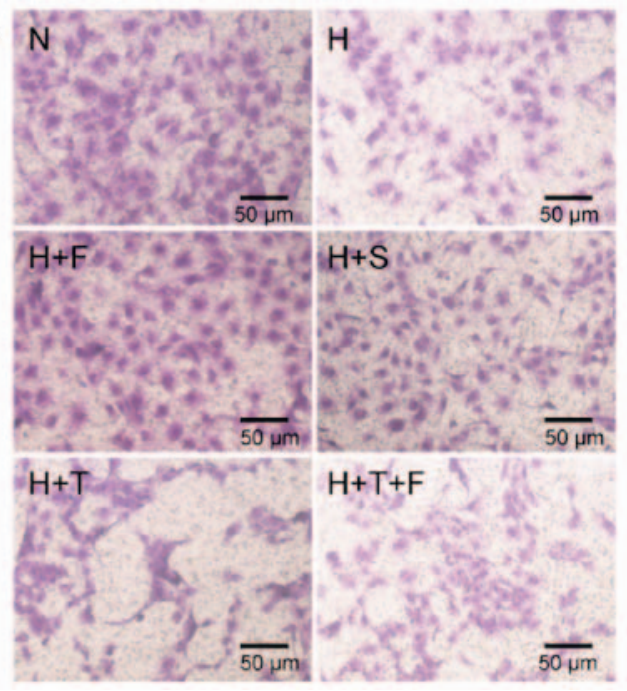

B

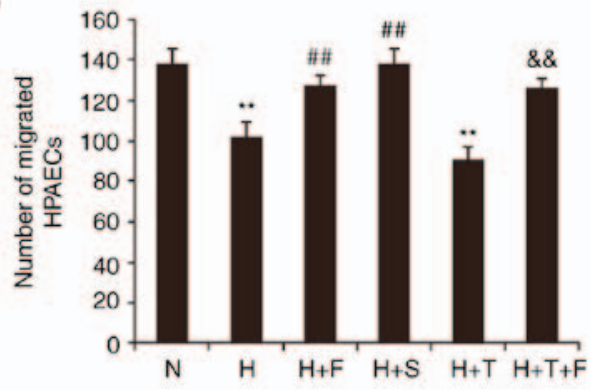

Figure 5. (A and B) Effect of FGF21 on the migratory ability of HPAECs. HPAEC migration was assessed using Transwell migration chambers. Representative images are shown for the migrated cells in each experimental group (magnification, $\mathrm{x} 100$; scale bar, $50 \mu \mathrm{m}$ ), as well as quantification of the numbers of migrated HPAECs. Data are expressed as the mean \pm standard deviation $(n=6) .{ }^{* *} \mathrm{P}<0.01$ vs. the $\mathrm{N}$ group; ${ }^{\# \#} \mathrm{P}<0.01$ vs. the $\mathrm{H}$ group; ${ }^{\text {\&\&}} \mathrm{P}<0.01$ vs. the $\mathrm{H}+\mathrm{T}$ group. FGF21, fibroblast growth factor 21; HPAECs, human pulmonary arterial endothelial cells; N, normoxia; H, hypoxia; F, FGF21; S, salubrinal; T, tunicamycin.

A

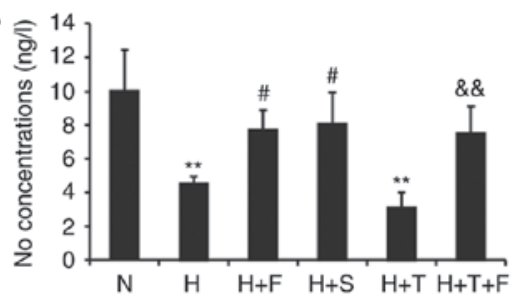

B

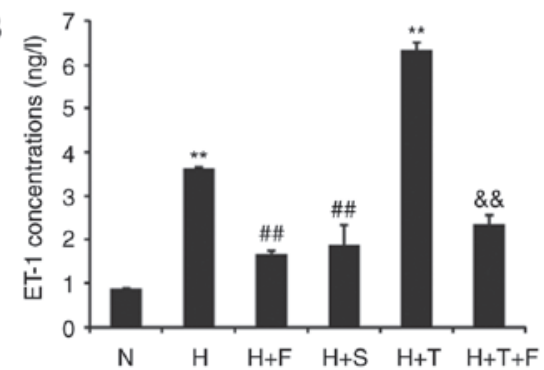

C

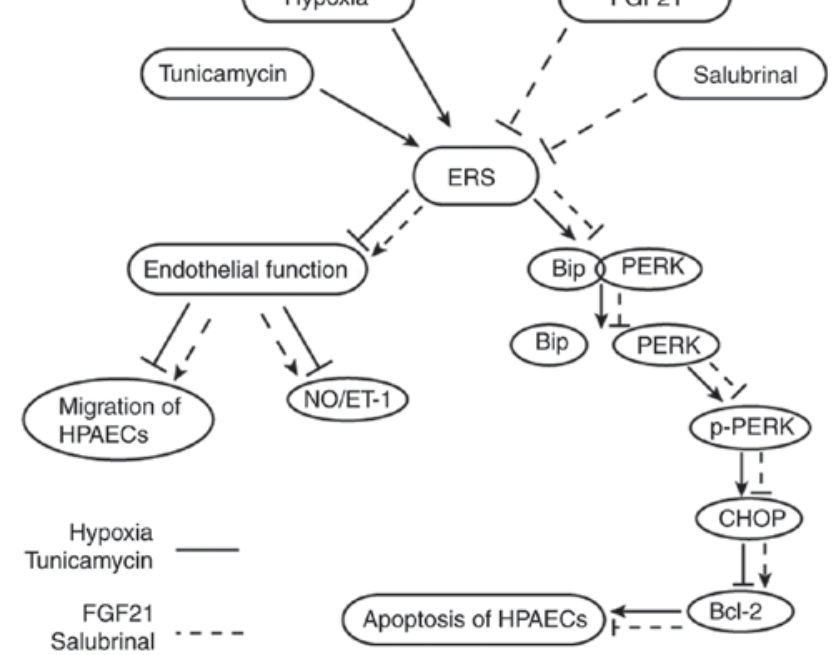

Figure 6. Effect of FGF21 on NO and ET-1 secretion in HPAECs. (A) HPAECs were treated as indicated and at the end of treatment, the cell culture medium was collected and assayed by ELISA for the levels of secreted NO and (B) the levels of secreted ET-1. Data are expressed as the mean \pm standard deviation $(\mathrm{n}=3) .{ }^{* *} \mathrm{P}<0.01$ vs. the $\mathrm{N}$ group; ${ }^{\#} \mathrm{P}<0.05$ and ${ }^{\# \#} \mathrm{P}<0.01$ vs. the $\mathrm{H}$ group; \& ${ }^{\&} \mathrm{P}<0.01$ vs. the $\mathrm{H}+\mathrm{T}$ group. (C) Schematic of the proposed mechanism by which FGF21 attenuates hypoxia-induced apoptosis and dysfunction by alleviating ERS in HPAECs. FGF21, fibroblast growth factor 21; NO, nitric oxide; ET-1, endothelin-1; HPAECs, human pulmonary arterial endothelial cells; ERS, endoplasmic reticulum stress; N, normoxia; H, hypoxia; F, FGF21; S, salubrinal; T, tunicamycin; $\mathrm{BiP}$, binding immunoglobulin protein; p-, phosphorylated; PERK, protein kinase R-like endoplasmic reticulum kinase; CHOP, transcription factor C/EBP homologous protein; Bcl-2, B cell lymphoma-2.

self-phosphorylation to initiate ERS (27-29). Chronic or severe ERS would activate ERS-dependent apoptosis, including the CHOP and caspase-mediated apoptotic pathways. The CHOP-mediated pathway is associated with PERK/eIF $2 \alpha$ mediated transcriptional activation of the C/EBP-homologous protein CHOP, which then downregulates the expression of the antiapoptotic mediator Bcl-2. Activation of the caspase cascade is a well-known proapoptotic event that is also involved in ERS-induced apoptosis (28). Several caspases are believed to serve roles in this process, including caspase-2, caspase-4 (human), caspase-12 (rodents), caspase-7, caspase-3 and caspase-9. It has been suggested that caspase-12 is specific to death signals in ERS rather than to other cell death mechanisms $(29,30)$. The present results demonstrated that hypoxic conditions activated PERK/CHOP signaling and increased the expression of human caspase-4, which may participate in the apoptosis and damage of HPAECs.

Both in yeast and in mammalian cells, UPR signaling can be initiated by the use of chemical agents that induce ERS, such as the N-linked glycosylation inhibitor tunicamycin, the calcium pump inhibitor thapsigargin, and the reducing agent dithiothreitol (31). A known ERS inducer tunicamycin mediates the degradation of ceramide synthase 6 (CerS6) and subsequent ATF-6 and caspase-3 activation. Senkal et al (32) 
reported that downregulation of CerS6 increased ATF-6 activation, as determined by increased expression of its downstream target CHOP in UM-SCC-22A cells. CerS6 knockdown also activated CHOP in human squamous lung cancer H1650 cells, leading to cell death (32).

An increasing number of studies have reported that ERS inhibitors protect cells under adverse stimuli. In the current study, salubrinal was used as an ERS inhibitor. Salubrinal, a selective inhibitor of cellular complexes, dephosphorylates eIF2 $\alpha$. During ERS, PERK, an ER-resident transmembrane protein, oligomerizes and phosphorylates eIF $2 \alpha$ at serine 51 (33). Salubrinal induces rapid and robust eIF $2 \alpha$ phosphorylation and its downstream effects, including downregulation of cyclin D1 and upregulation of growth arrest and DNA damage inducible protein 34 and CHOP (34). The phosphorylation of eIF2a is cytoprotective during ERS. In recent years, another ERS inhibitor, 4-phenylbutyric acid (4-PBA), has also been employed. 4-PBA can inhibit ERS as a chemical chaperone by stabilizing peptide structures, improving luminal folding capacity, and attenuating cell damage. Wu et al (35) demonstrated that 4-PBA improved pulmonary arterial remodeling and suppressed the expression of ERS indicators, including GRP78, GRP94, ATF6, IRE-1, PERK, CHOP and Bcl-2, in a monocrotaline-induced PAH rat model.

FGF21 is a member of the FGF family. In the adult organism, FGFs are homeostatic factors and exhibitfunctions in tissue repair and response to injury (36). FGF21 is an endocrine regulator that participates in lipid and glucose metabolism, and has recently been reported to protect cardiac endothelial cells from damage and suppress inflammatory responses. In the present study, the role of FGF21 in hypoxia-induced apoptosis and dysfunction was investigated in HPAECs. Studies by Schaap et al (37) suggest that FGF21 expression is regulated by ERS. The authors reported that FGF21 mRNA levels are increased by triglyceride-induced ERS in rat H4IIE cells and rat primary hepatocytes. Wan et al (8) demonstrated that FGF21 is the target gene of CHOP, and that transcription and mRNA stabilization are responsible for the CHOP-mediated induction of FGF21 expression in ERS, indicating that ERS is the key mechanism of FGF21 regulation in several metabolic diseases. In addition, Jiang et al (38) indicated that intraperitoneal administration of the ER stressor tunicamycin activates ERS, which results in liver steatosis associatedwith upregulated expression of hepatic FGF21 in the liver. Furthermore, administration of recombinant FGF21 in mice alleviates PERK/CHOP signaling in the liver, resulting in the reversal of ERS-induced liver steatosis. In addition tothe evidence presentedabove, previous studies have indicated that FGF21 and ERS are closely associated in metabolism. FGF21 may act as an inhibitor, similar to salubrinal or 4-PBA, and attenuate ERS to protect cells from damage. In the present study, theresults following treatment of HPAECs with hypoxia and the ERS agonist tunicamycin demonstrated that administration of FGF21 ameliorated the hypoxia-induced endothelial apoptosis and dysfunction, and improved the viability of HPAECs. These observations are consistent with previous studies on the cardiovascular system, indicating that FGF21 could prevent damage to cardiac endothelial cells (18). In the present study, the results revealed that FGF21 downregulated p-PERK andsubsequently increased the expression of CHOP, ultimately upregulating the expression of the antiapoptotic mediator Bcl-2, and downregulating the expression of caspase-4, which decreased the number of apoptotic cells and enhanced the viability of HPAECs. Hypoxia and tunicamycin resulted in an expanded shape of the ER in HPAECs, while this effect was notably normalized following treatment with FGF21 and the ERS inhibitor salubrinal. Furthermore, the results indicated that FGF21 alleviated hypoxia-induced endothelial dysfunction, by decreasing the secretion of ET-1, increasing the secretion of $\mathrm{NO}$ and repairing damage to the cell migration ability, processes that are involved in the pathogenesis of hypoxia-induced PAH (39).

The balance between NO and ET-1 has a significant role in the development of hypoxia-induced PAH. In patients with $\mathrm{PAH}$, changes in the expression of various endothelial vasoactive mediators, including NO, ET-1, prostacyclin, serotonin and thromboxane, have been increasingly recognized. Since most of these mediators affect the growth of smooth muscle cells, this may facilitate the development of pulmonary vascular hypertrophy. The present study aimed to explore the mechanism of the apoptosis and dysfunction of HPAECs under conditions of hypoxia through observing the cell morphology and function, and protein level changes. Endothelial function was investigated by assaying for the cell migration ability, and the secretion levels of NO and ET-1. Overproduction of eNOS, which stimulates the conversion of L-arginine to citrulline, producing NO (40), prevents hypoxia-induced PAH in transgenic mice (41). Several previous studies suggest that NO protects against hypoxia-induced vasoconstriction in the lungs, inhibits smooth muscle proliferation and platelet aggregation, and decreases the secretion of ET-1 (39). ET-1 expression is elevated in animal models of PH and in patients with $\mathrm{PH}$ (39). ET-1 receptor antagonists, such as bosentan, improve the functional status of patients and other indices of PH-related morbidity (42). The present results revealed that hypoxia reduced the secretion of $\mathrm{NO}$ and increased the secretion of ET-1 in HPAECs. In addition, FGF21 and the ERS inhibitor salubrinal were demonstrated to improve the secretion of NO and ET-1 in HPAECs under conditions of hypoxia.

In summary, the results of the present study revealed that ERS is a key mechanism involved in the hypoxia-induced apoptosis and dysfunction of HPAECs, which are important processes in the initiation of hypoxia-induced PAH. FGF21 attenuated the hypoxia-induced dysfunction and apoptosis of HPAECs through diminishing ERS, which was mediated by the PERK/CHOP signaling pathway (as illustrated in Fig. 6C), and by the inhibition of caspase-4 expression. Although FGF21 was demonstrated to alleviate the main ERS-dependent death signaling pathway in HPAECs, the mechanism by which FGF21 is associated with ERS has yet to be fully elucidated. Additionally, the role of FGF21 in ERS and PAH in vivo remains unclear and requires further research. However, the present findings strongly support the notion that FGF21 may havepromising therapeutic potential forthe treatment of hypoxia-induced PAH.

\section{Acknowledgements}

Not applicable. 


\section{Funding}

The present study was supported by the Project of Health Department of Zhejiang Province of China (grant no. 2016DTA005), the Natural Science Foundation Grants of Zhejiang Province (grant no. Y17H010028) and the Chinese National Natural Science Foundation Grants (grant no. 81473406).

\section{Availability of data and materials}

The analyzed datasets generated during the study are available from the corresponding author on reasonable request.

\section{Authors' contributions}

AC designed and performed the experiments, analysed the data and wrote the paper; $\mathrm{XH}$ and LW designed the experiments and helped to draft the manuscript; JL, JZ and XW performed the experiments and collected data. ZX and MX performed the experiments; ZC, ML, DY and ZH participated in the study design and supervised the study; MC and PW collected data and performed the analysis. All authors read and approved the final manuscript.

\section{Ethics approval and consent to participate}

Not applicable.

\section{Consent for publication}

Not applicable.

\section{Competing interests}

The authors declare that they have no competing interests.

\section{References}

1. Sutendra G and Michelakis ED: The metabolic basis of pulmonary arterial hypertension. Cell Metab 19: 558-573, 2014.

2. Huang X, Zou L, Yu X, Chen M, Guo R, Cai H, Yao D, $\mathrm{Xu} \mathrm{X}$, Chen Y, Ding C, et al: Salidroside attenuates chronic hypoxia-induced pulmonary hypertension via adenosine A2a receptor related mitochondria-dependent apoptosis pathway. J Mol Cell Cardiol 82: 153-166, 2015.

3. Voelkel NF and Cool C: Pathology of pulmonary hypertension. Cardiol Clin 22: 343-351, 2004.

4. Eddahibi S, Guignabert C, Barlier-Mur AM, Dewachter L, Fadel E, Dartevelle P, Humbert M, Simonneau G, Hanoun N, Saurini F, et al: Cross talk between endothelial and smooth muscle cells in pulmonary hypertension: Critical role for serotonin-induced smooth muscle hyperplasia. Circulation 113: 1857-1864, 2006.

5. Humbert M, Montani D, Perros F, Dorfmüller P, Adnot S and Eddahibi S: Endothelial cell dysfunction and cross talk between endothelium and smooth muscle cells in pulmonary arterial hypertension. Vascul Pharmacol 49: 113-118, 2008.

6. Sahara M, Sata M, Morita T, Hirata Y and Nagai R: Nicorandil attenuates monocrotaline-induced vascular endothelial damage and pulmonary arterial hypertension. PLoS One 7: e33367, 2012

7. Farkas L, Farkas D, Ask K, Möller A, Gauldie J, Margetts P, Inman M and Kolb M: VEGF ameliorates pulmonary hypertension through inhibition of endothelial apoptosis in experimental lung fibrosis in rats. J Clin Invest 119: 1298-1311, 2009.

8. Wan XS, Lu XH, Xiao YC, Lin Y, Zhu H, Ding T, Yang Y, Huang Y, Zhang Y, Liu YL, et al: ATF4- and CHOP-dependent induction of FGF21 through endoplasmic reticulum stress. Biomed Res Int 2014: 807874, 2014.
9. Walter P and Ron D: The unfolded protein response: From stress pathway to homeostatic regulation. Science 334: 1081-1086, 2011.

10. Muñoz JP and Zorzano A: Endoplasmic reticulum stress enters a Nogo Zone. Sci Transl Med 3: 88ps26, 2011.

11. Koyama M, Furuhashi M, Ishimura S, Mita T, Fuseya T, Okazaki Y, Yoshida H, Tsuchihashi K and Miura T: Reduction of endoplasmic reticulum stress by 4-phenylbutyric acid prevents the development of hypoxia-induced pulmonary arterial hypertension. Am J Physiol Heart Circ Physiol 306: H1314-H1323, 2014.

12. Fan XF, Li WJ, Chen ZQ, Wang XR, Kong XX, Mao SZ, Hu LG and Gong YS: Changes of endoplasmic reticulum stress-induced apoptosis in pulmonary tissue of rats with hypoxic pulmonary hypertension. Zhongguo Ying Yong Sheng Li Xue Za Zhi 27: 270-274, 2011 (In Chinese).

13. Ost M, Coleman V, Kasch J and Klaus S: Regulation of myokine expression: Role of exercise and cellular stress. Free Radic Biol Med 98: 78-89, 2016.

14. Inagaki T: Research perspectives on the regulation and physiological functions of FGF21 and its association with NAFLD. Front Endocrinol (Lausanne) 6: 147, 2015.

15. Kim SH, Kim KH, Kim HK, Kim MJ, Back SH, Konishi M, Itoh N and Lee MS: Fibroblast growth factor 21 participates in adaptation to endoplasmic reticulum stress and attenuates obesity-induced hepatic metabolic stress. Diabetologia 58: 809-818, 2015.

16. Shimizu M, Morimoto H, Maruyama R, Inoue J and Sato R: Selective regulation of FGF19 and FGF21 expression by cellular and nutritional stress. J Nutr Sci Vitaminol (Tokyo) 61: 154-160, 2015.

17. Guo Q, Xu L, Liu J, Li H, Sun H, Wu S and Zhou B: Fibroblast growth factor 21 reverses suppression of adiponectin expression via inhibiting endoplasmic reticulum stress in adipose tissue of obese mice. Exp Biol Med (Maywood) 242: 441-447, 2017.

18. Lü Y, Liu JH, Zhang LK, DU J, Zeng XJ, Hao G, Huang J, Zhao DH, Wang GZ and Zhang YC: Fibroblast growth factor 21 as a possible endogenous factor inhibits apoptosis in cardiac endothelial cells. Chin Med J (Engl) 123: 3417-3421, 2010.

19. Li J, Zhou J, Zhang D, Song Y, She J and Bai C: Bone marrow-derived mesenchymal stem cells enhance autophagy via $\mathrm{PI} 3 \mathrm{~K} / \mathrm{AKT}$ signalling to reduce the severity of ischaemia/reperfusion-induced lung injury. J Cell Mol Med 19: 2341-2351, 2015.

20. Gong T, Wang Q, Lin Z, Chen ML and Sun GZ: Endoplasmic reticulum (ER) stress inhibitor salubrinal protects against ceramide-induced SH-SY5Y cell death. Biochem Biophys Res Commun 427: 461-465, 2012.

21. Guoliang H, Kunlun H, Li F, Xin L and Ruijun L: Salubrinal protects endoplasmic reticulum of cardiac muscle cells against stress-associated apoptosis. Jun Yi Jin Xiu Xue Yuan Xue Bao 31: 483-485, 2010 (In Chinese).

22. Wang H, Zuo X, Wang Q, Yu Y, Xie L, Wang H, Wu H and Xie W: Nicorandil inhibits hypoxia-induced apoptosis in human pulmonary artery endothelial cells through activation of mitoKATP and regulation of eNOS and the NF- $\kappa$ B pathway. Int J Mol Med 32: 187-194, 2013.

23. Morecroft I, White K, Caruso P, Nilsen M, Loughlin L, Alba R, Reynolds PN, Danilov SM, Baker AH and Maclean MR: Gene therapy by targeted adenovirus-mediated knockdown of pulmonary endothelial Tph1 attenuates hypoxia-induced pulmonary hypertension. Mol Ther 20: 1516-1528, 2012.

24. Paulin R and Michelakis ED: The metabolic theory of pulmonary arterial hypertension. Circ Res 115: 148-164, 2014.

25. Mao SZ, Fan XF, Xue F, Chen R, Chen XY, Yuan GS, Hu LG, Liu SF and Gong YS: Intermedin modulates hypoxic pulmonary vascular remodeling by inhibiting pulmonary artery smooth muscle cell proliferation. Pulm Pharmacol Ther 27: 1-9, 2014

26. Wang S and Kaufman RJ: The impact of the unfolded protein response on human disease. J Cell Biol 197: 857-867, 2012.

27. Liu Z, Lv Y, Zhao N, Guan G and Wang J: Protein kinase R-like ER kinase and its role in endoplasmic reticulum stress-decided cell fate. Cell Death Dis 6: e1822, 2015.

28. Vannuvel K, Renard P, Raes M and Arnould T: Functional and morphological impact of ER stress on mitochondria. J Cell Physiol 228: 1802-1818, 2013.

29. Rutkowski DT and Kaufman RJ: A trip to the ER: Coping with stress. Trends Cell Biol 14: 20-28, 2004.

30. Szegezdi E, Fitzgerald U and Samali A: Caspase-12 and ER-stress-mediated apoptosis: The story so far. Ann NY Acad Sci 1010: 186-194, 2003.

31. Richardson CE, Kinkel S and Kim DH: Physiological IRE-1-XBP-1 and PEK-1 signaling in caenorhabditis elegans larval development and immunity. PLoS Genet 7: e1002391, 2011. 
32. Senkal CE, Ponnusamy S, Manevich Y, Meyers-Needham M Saddoughi SA, Mukhopadyay A, Dent P, Bielawski J and Ogretmen B: Alteration of ceramide synthase 6/C16-ceramide induces activating transcription factor 6-mediated endoplasmic reticulum (ER) stress and apoptosis via perturbation of cellular $\mathrm{Ca}^{2}$ and ER/Golgi membrane network. J Biol Chem 286: 42446-42458, 2011.

33. Schröder M and Kaufman RJ: ER stress and the unfolded protein response. Mutat. Res 569: 29-63, 2005.

34. Boyce M, Bryant KF, Jousse C, Long K, Harding HP, Scheuner D, Kaufman RJ, Ma D, Coen DM, Ron D and Yuan J: A Selective Inhibitor of eIF2alpha dephosphorylation protects cells from ER stress. Science 307: 935-939, 2005.

35. Wu Y, Adi D, Long M, Wang J, Liu F, Gai MT, Aierken A, Li MY, Li Q, Wu LQ, et al: 4-Phenylbutyric acid induces protection against pulmonary arterial hypertension in rats. PLoS One 11: e0157538, 2016.

36. Ornitz DM and Itoh N: Fibroblast growth factors. Genome Biol 2: REVIEWS3005, 2001.

37. Schaap FG, Kremer AE, Lamers WH, Jansen PL and Gaemers IC: Fibroblast growth factor 21 is induced by endoplasmic reticulum stress. Biochimie 95: 692-699, 2013.
38. Jiang S, Yan C, Fang QC, Shao ML, Zhang YL, Liu Y, Deng YP, Shan B, Liu JQ, Li HT, et al: Fibroblast growth factor 21 is regulated by the IRE1 $\alpha$-XBP1 branch of the unfolded protein response and counteracts endoplasmic reticulum stress-induced hepatic steatosis. J Biol Chem 289: 29751-29765, 2014.

39. Budhiraja R, Tuder RM and Hassoun PM: Endothelial dysfunction in pulmonary hypertension. Circulation 109: 159-165, 2004.

40. Marletta MA: Nitric oxide synthase structure and mechanism. J Biol Chem 268: 12231-12234, 1993.

41. Ozaki M, Kawashima S, Yamashita T, Ohashi Y, Rikitake Y, Inoue N, Hirata KI, Hayashi Y, Itoh H and Yokoyama M: Reduced hypoxic pulmonary vascular remodeling by nitric oxide from the endothelium. Hypertension 37: 322-327, 2001.

42. Rubin LJ, Badesch DB, Barst RJ, Galie N, Black CM, Keogh A, Pulido T, Frost A, Roux S, Leconte I, et al: Bosentan therapy for pulmonary arterial hypertension. N Engl J Med 346: 896-903, 2002. 